\title{
INTERACTIVE RELATIONSHIP BETWEEN PROPERTY AND CONTRACT LAW-SECURITY RIGHTS PERSPECTIVE
}

\author{
Rongxin Zeng*
}

\begin{abstract}
Property law and Contract law are two of the most important fields of the private law. There exist some obvious distinctions between property and contract law. Meanwhile, properties are usually caused and influenced by contracts; the validity and forms of contracts are also influenced by property law. Therefore, there's an interactive relationship between them. The present research aims to analyze this interactive relationship from the perspective of the security rights which are normally considered as some typical forms of property rights.
\end{abstract}

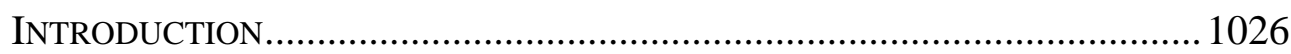

I. DistinCTION BETWEEN PROPERTY AND CONTRACT LAW ........................1027

A. Principle of Numerus Clausus ............................................ 1027

B. $\quad$ Principle of Freedom of Contract ........................................... 1028

C. Universal Effects of Property Rights and Effects of Contract 1028

II. SECURITY RigHTS IN MOVABLES AND CONTRACT LAW ..........................1029

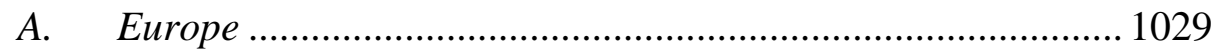

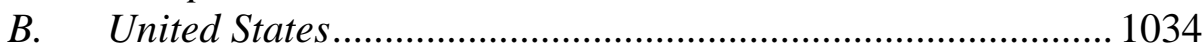

III. SECURITY RIGHTS IN IMMOVABLES AND CONTRACT LAW .................... 1038

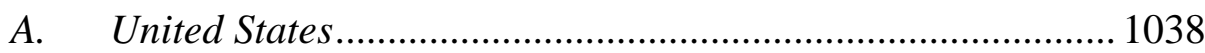

B. Europe …………........................................................... 1039

IV. INTERACTION OF PROPERTY AND CONTRACT LAW ON SECURITY RIGHTS

CONCLUSION. 1041

\section{INTRODUCTION}

Property law defines into a field of law governing different types of ownership in property, either real or personal property. These concepts manifest in various statutes from the modern law defining the accompanying rights of ownership in such property. On the other hand, contract law entails the formation and fulfillment of promises. The aspects of this law become distinct in various countries, mostly based on the common law. A contract, therefore, defines an agreement enforceable in

\footnotetext{
* Rongxin Zeng, Lecturer, Ph.D., Law School, Shanghai University of Political Science and Law, China, 201701. Research fields: Civil Law, Commercial Law.
} 
court involving two or more parties in agreement of performance or nonperformance of some action presently or in the future.

\section{Distinction BETWEEN PROPERTY AND CONTRACT LAW}

\section{A. Principle of Numerus Clausus}

The law limits the ability of owners of assets in the granting of partial rights in assets binding subsequent holders of the remaining rights in the asset. This is commonly referred to as numerus clausus principle, and describes the recognition of only a limited list of mandatory forms in property law. The distinguishing feature rests on the fact that, a property right becomes enforceable against both the original grantor of the right and third parties to whom such rights have been transferred. From a property law context, the liability of a property right rests on the person in its possession. ${ }^{1}$ For instance, consider the case of a tenant renting a piece of land: he has a property right in the land if he enforces his rights in the land against the landlord and also other individuals to whom the land is transferred by the landlord as per his interest in the land.

Property law seeks to address this matter by defining and offering standardized forms with desirable attributes and labels. The expression “copyright”, for instance, presents a simple label that denotes a complicated package consisting of well-defined property rights intended for serving the requirements of authors and publishers. ${ }^{2}$ Through such limitation of property rights to a set of standard forms, the law minimizes on related information processing costs of individuals seeking to acquire rights to certain property.

The law on property, thus, proves challenging in the provision of mechanisms aimed at solving problems of verification, commonly referred to as assurance of effective notice. As a matter of resolve, it employs a range of rules for verification. ${ }^{3}$ These rules determine the conditions under which transfer of rights will occur, especially as relates to a third party. One such rule entails, the concept of possession presenting the most primitive and common means. Theoretically, verification is only based on possession

\footnotetext{
${ }^{1}$ Alpa G., Bar C., Drobnig U. \& European Commission, The Interaction of Contract LaW and TORT AND PRoperty LaW IN EUROPE: A Comparative Study (Munchen: Sellier- European Law Publishers 2004).

${ }^{2}$ Simon J., European Contract Law: Draft Code Published (2011). Available at http://www.cliffordchance.com/publicationviews/publications/2011/05/european_contractlawdraftcod epublished.html (last visited May 27, 2013).

${ }^{3}$ Alpa G., Bar C., Drobnig U. \& European Commission, supra note 1.
} 
depicting as a simple process. It provides that, the party with physical possession of the property retains the full rights and transfer of such property is accompanied by those rights.

\section{B. Principle of Freedom of Contract}

The principle of freedom of contract becomes the dominant concept in the law on contract. It requires that, parties possess the freedom to make agreements on own terms and with a desired party, without any intrusion of the courts or Acts. It becomes evident that, a numerus clausus of property rights existing in many states develops in absolute contrast to freedom of contract principle which stands out as a forming part of contract law. However, according to some studies, it has been a claim that, the contrast is not complete as in the framework of contractual rights in property, the involved parties possess the freedom to agree or disagree on institution of an admitted real right.

Additionally, the parties have the power to agree on those aspects relating to the desired property right under which the law fails to regulate through mandatory rules or total lack of regulation, occurring within the stated limit. The intention to formulate new property rights, even in permitted circumstances, practically takes place in unusual and rare cases. The models offered by law provide form the majority of contractual property rights. Thus, in this viewpoint, property law's limitation on the autonomy of either party portrays a distinguishing feature from contract law.

\section{Universal Effects of Property Rights and Effects of Contract}

A key and particular feature of proprietary rights comes out in their universal impacts. For contractual rights, the parties form an agreement existing only between them, while proprietary rights extend such rights against the entire world, described as erga omnes. Most cases show the universal effect of proprietary rights as relating and subject to conformity with stipulated methods of publicity, mainly for real rights in the case of immovables as well as security rights in movables. The major fundamental aspect of a proprietary right and the consequent universal effects manifests clearly in the essential consequences drawn from it: an individual entitled to such a right has the capability to enforce it against a holder of the asset without entitlement to such custody (possession) as relates to the right or legitimate holder. 


\section{SECURITY RighTS IN MOVABLES AND CONTRACT LAW}

Movables, also known as personal property, entail anything other than land with the capability of ownership, encompassing money, notes, intellectual rights, stocks and intangibles. It classifies broadly into two: tangibles (corporeals) and intangibles (incorporeal). ${ }^{4}$ The former includes things like merchandise, jewelry, animals and so on; whereas intangibles refer to items such as bonds, patents and copyrights. A security right in a movable asset describes any finite proprietary right in the property which grants the secured creditor better satisfaction of related rights from the full asset. The term "finite proprietary right" indicates that, a security right entails the involved liability to the complete ownership of such an asset. ${ }^{5}$ Conventionally, the security provider holds the right to ownership, though a third party may also have authority to create that liability in his or her own name. The limited right entitles the secured creditor to special value creation from the asset. The preferential satisfaction becomes the essence of security rights in property.

\section{A. Europe}

The Draft Common Frame of Reference intervenes deeply into the law on property as it affects movables. Goods fall under corporeal movables, with the class encompassing incorporeals while excluding immovables. Contracts influencing on movables receive cover for general and specific contracts including sale and hire. ${ }^{6}$ In recent times, non-possessory security in movables becomes paramount, with the present contribution being limited to contractual security rights.

The pledge stands out as the classical form of possessory security without considering the issue of qualification. By "possessory" we mean that, the pledged corporeal goods are held by the secured creditor and not by the debtor or a third party. ${ }^{7}$ The legal criteria for determining a possessory pledge is seen from the requirement that, the debtor must be dispossessed of such goods. Thus, the economic function of pledges is determined by the strict criterion used. Use of pledges mainly applies for goods which the debtor does not urgently need for trade or manufacturing purposes, but

\footnotetext{
${ }^{4}$ Cisg.LAW., Introduction to Principles of European Contract LaW (2010). Available at http://www.cisg.law.pace.edu/cisg/text/peclcomments.html (last visited May 27, 2013).

${ }^{5}$ COMMISSION ON EUROPEAN CONTRACT LAW PRINCIPLES OF EUROPEAN CONTRACT LAW, PART 2 (Boston, UK: Wolters Kluwer Law \& Business 1999).

${ }^{6}$ Alpa G., Bar C., Drobnig U. \& European Commission, (2004), supra note 1.

${ }^{7}$ CisG.LAW., INTRODUCTION TO PRINCIPLES OF EUROPEAN CONTRACT LAW (2010), supra note 4.
} 
necessary for those dispensable for the time being, such as luxury products and jewelry.

The means used in creation of a possessory security depicts the characteristic nature of the resulting pledge. The debtor remains to be dispossessed of the goods through transfer of possession to the secured creditor or to a third party after a mutual agreement. This becomes an essential and permanent requirement that deserves fulfillment until the pledge is terminated. It seeks to serve two major functions: the process makes it hard for the debtor to dispose of such goods to a third party; and he/she cannot develop a misleading impression in the minds of other creditors as relates to ownership of the corporeals that may be available for preferential satisfaction of any leveled claims. ${ }^{8}$ Additionally, particular pledges must accompany certain formalities, for instance, in Italy, certain documentation becomes applicable unless the creditor entails a credit institution.

The debtor, after dispossession, remains the owner of such goods, while the secured creditor takes the position of a holder, commonly referred to as bailment in English law. The secured creditor becomes responsible for the maintenance and safekeeping of the pledged goods. In most places, breach of this role results to a liability in form of damages or restitution of the goods such as in France. The time-oriented principle of "prior tempore, potior jure" requires that, the rank between various secured creditors becomes a determinant of the time of creation. ${ }^{9}$ It applies between different creditors with contractual, statutory security rights as well as execution creditors. In modern times, the debtor's insolvency affects the rights of the pledge including the right of enforcement. As a general agreement, if proceeds from enforcement fail to cover the secured claim, the outstanding payment may be claimed from the estate as a dividend, with a surplus being paid to an administrator.

Default of payment by the debtor prompts the creditor to enforce his proprietary right of satisfaction from the pledged goods. ${ }^{10}$ The arising conflict evokes a number of differing solutions, for example, an agreement by the parties to pass ownership to the creditor while involving an expert to determine the market value at the appropriation period, as in France. Following maturity, the involved parties can freely agree on the means of enforcement. England provides for the most tolerant method that, entails

\footnotetext{
${ }^{8}$ Young M., Understanding Contract Law (London: Routledge 2009).

${ }^{9}$ Commission on European Contract LaW, PRINCIPLES OF EUROPEAN CONTRACt LAW (1999), supra note 5.

${ }^{10}$ Alpa G., Bar C., Drobnig U. \& European Commission, (2004), supra note 1.
} 
sale of the goods by the secured creditor in case of default. ${ }^{11}$ This only requires that, the sale becomes "reasonable". Any surplus from the sale proceeds after the creditor's satisfaction of claims pass on to the debtor, and vice versa in case of deficits.

Non-possessory security describes forms of security where the movable assets remain in the debtor's hands undeliverable to the creditor or to a third party. ${ }^{12}$ Thus, the economic value portrays from the advantages of retaining the goods as held by the debtor. For instance, an individual consumer will use household goods as security for the secured goods. The contemporary legal regime shows a less existent form of law on nonpossessory security as historical roots are short. This uncoordinated development brings about less harmony between various countries. The variety of legislative, doctrinal and judicial resolves aimed at coping with certain needs classify into a few basic models. ${ }^{13}$ Consequently, two basic models clearly stand out: the pledge and ownership of an asset.

The pledge or charge intends to serve as security in corporeals, whereas the latter comes out as a complex property right not designed for security purposes. The requirements for creation of a non-possessory pledge differ from those of a possessory pledge, since in the former, the debtor need not dispossess himself of the security. ${ }^{14}$ Legislators employ more or less effective substitute for publicity meant to inform interested individuals about existing charges on particular assets of their potential debtor. This becomes an essential requirement for the validity of the security also affecting third parties. Registration of the security agreement becomes one of the most common and effective method of substitute publicity.

For non-possessory security, it becomes paramount to enhance the creation of a security in a fund, which entails a mass of assets consisting of changing elements. In England, the use of floating charge is a clear manifest of this technique as well as the pledge on an agricultural tenant's stock in Germany. Possessory pledges demand that, possession be transferred to the creditor thus implying the necessity to keep the secured assets separate from the creditor's corresponding assets. This situation corresponds to the contemporary non-possessory pledge in the debtor's assets. Nonetheless, both cases require mutual consent between the involved parties, hence the need for corresponding rules in every jurisdiction.

Protection against third parties for non-possessory goods is similar to

\footnotetext{
${ }^{11}$ Cisg.law., InTRoduction to Principles of European Contract LaW (2010), supra note 4.

${ }^{12}$ KLASS G., Contract Law IN tHe USA (Boston, Kluwer Law 2010).

${ }^{13}$ Cisg.laW., InTROdUCTION TO PRINCIPLES OF EUROPEAN CONTRACT LAW (2010), supra note 4.

${ }^{14}$ Simon J., European Contract LaW: Draft Code Published (2011), supra note 2.
} 
that of possessory goods. However, the non-possessory creditor is affected by certain demerits as relates to procedures and rules in insolvency proceedings against debtor's property. ${ }^{15}$ This is in line with the enforcement of the security as the insolvency administrator holds the security. The debtor's decision to dispose of the security without the creditor's consent also springs up concerns of protection. ${ }^{16}$ The concept of good faith lacks merit in some cases since the legal provisions differ across regions and are uncertain. For instance, the parties may accept the legislator's invitation to apply an optional publicity by means of a sign as an attachment to the security.

Non-possessory pledges receive enforcement in a similar way to possessory security as the same rules remain applicable. As a matter of note, two special features stand out: the secured creditor cannot begin to enforce his security until he obtains the said collateral from the debtor in possession, and thus has to request its transfer to him; the enforcement of an enterprise pledge slightly differs from that of a pledge against certain assets. ${ }^{17}$ The holder of an English floating charge, for example, becomes permitted to appoint a receiver responsible for the administration of the security so as to secure an optimal return for it.

Intangible personal property, such as intellectual rights and debts become most eminent in these times with a corresponding growing economic importance. Subsequently, they acquire considerable use as collateral for securing credits. ${ }^{18}$ Similar models accrue for incorporeals (intangibles) vis-à-vis utilization of monetary claims as security: it involves a pledge or a full transfer to the creditor, commonly known as an assignment. The basic legal issue is also identical as by an assignment of a claim, the creditor acquires excess rights than those required for security purposes. ${ }^{19}$ The question thus arises as to how and whether the powers are to be limited in particular situations.

For monetary claims, the pledge is governed by the common rules relating to pledges. Nonetheless, under the narrow possessory ideology of the pledge developed, the essential dispossession of the pledgor of an incorporeal or intangible cannot be recognized. Alternatively, the Civil Codes of England demand for notification of the debtor of the pledged claim or the account debtor. ${ }^{20}$ On the contrary, the French laws require a document

\footnotetext{
${ }^{15}$ Alpa G., Bar C., Drobnig U. \& European Commission, (2004), supra note 1.

${ }^{16}$ KLASS G., CONTRACT LAW IN THE USA (2010), supra note 12.

${ }^{17}$ KLASS G., CONTRACT LAW IN THE USA (2010), supra note 12.

${ }^{18}$ Alpa G., Bar C., Drobnig U. \& European Commission, (2004), supra note 1.

${ }^{19}$ Cisg.LAW., INTROdUCtion to Principles of EuRopean Contract LAW (2010), supra note 4.

${ }^{20}$ Wishart M., Contract LaW (Oxford, NY: Oxford University Press 2012).
} 
in writing as proof of validity of the pledge restricting the meaning of notification of the account debtor of the liable claim to such information that payment must be made for proper discharge. The required notification of the account debtor seems fundamental as an assurance that, he will pay his arrears to the pledge and not to the pledgor. Conversely, in most cases, the importance of notification to the account debtor proves to be commercially inconvenient. This stands out if there exists a significant number of such debtors owing modest amounts; since the reputation of pledgor is affected; and due to the dominant motion in many cases to leave the collection of the pledged claims to the pledgor in place of the pledge (to whom that pledgor ought to account and make payment). In English law, there exists no extension to the prevailing narrow thinking of the possessory pledge in case of intangibles, thus using the institution of the charge. ${ }^{21}$

The Civil Code in the Netherlands portrays an introduction of pledge without notification to the account debtor. It presents a similar situation as that for non-possessory pledges relating to tangibles. Similarly, the approach should be established through a public or registered private document. Where the pledgor fails in performance of his duty in relation to the pledge, or has reasons of being skeptic of such breach, the Dutch law demands that, the pledge notifies the account debtor. Additionally, in England and Wales, such monetary claims are made subject to an equitable charge without the debtor's notification. It is a requirement that, such charges be registered. It may be fixed or floating (consists of a changing fund of debts). ${ }^{22}$

Alternatively, instead of using a pledge for monetary claims with or without notification to the account debtor, the debts are transferred fully to the creditor by application of assignment. The approach corresponds to the security transfer of ownership. It however, becomes essential for the involved parties if it requires no notification. The assignment for security in Germany is guided by the common rules on the issue of assignment. There is a correlation between the Dutch and German rules for pledges of debts without notification as far as the right to collect the assigned debts is concerned.

Resulting impacts of an ordinary assignment remain restricted to the assignor's insolvency. This implies that, the creditor as the assignee loses the entitlement to distinguish the assigned claims from the assignor's insolvency estate. He is reduced to the status of a pledge limiting him to the right of preferential satisfaction from the proceeds of such claims. An

\footnotetext{
${ }^{21}$ Simon J., European Contract Law: Draft Code Published (2011), supra note 2.

${ }^{22}$ EUROPEAN COMMISSION, CONTACT LAW (2013). Available at http://ec.europa.eu/justice/contract (last visited May 27, 2013).
} 
outright sale of these claims to the creditor becomes disregarded as a charge thus not a subject to registration and other limitations as in the case of Wales and England.

\section{B. United States}

Security interest in most personal property which mainly includes tangibles is guided by the Uniform Commercial Code (UCC), a model law formulated in every state and the District of Columbia. Under Article 9 of the UCC clear guidelines concerning security interests in personal property are stipulated. ${ }^{23}$ US federal law and international treaties binding the country pre-empt the UCC in some cases. The provided article excludes particular types of property and transactions from its wide scope, for instance, most insurance policies, real property interests, chattel paper and payment intangibles forming part of business sale out of which they seem to erupt.

UCC describes goods as everything that is movable in the attachment of a security interest. It, therefore, includes: inventory, equipment, fixtures, standing timber awaiting cutting, unborn offspring of animals, grown crops or those still growing, and manufactured homes. On the other hand, the expression security interest defines into broad meanings. It develops from an interest in movables securing payment or performance of duty. This encompasses entitlement of property right by a seller of goods, as well as most consignments of goods. ${ }^{24}$ The UCC takes into account the interests of a purchaser of accounts, chattel papers and so on. The implication then becomes that, UCC treats most transactions as the development of a security interest appearing different on the face of it.

A security interest in personal property is required for attachment as proof of validity enhances its enforcement against the borrower or other third party acting as a grantor of the security interest or debtor. This demands that, the debtor possess rights in the security and enters into a sufficient security agreement which explains the form of security. ${ }^{25}$ It is not a requirement of UCC that, a debtor ought to receive a value almost or equal to the collateral's value. However, if this does not come up and the debtor falls into a position of insolvency, it remains that, a bankruptcy court sets aside the security interest as transfer in fraud.

\footnotetext{
${ }^{23}$ Mootz F. J., Principles of American Contract Law (Boston, MA: Wolters Kluwer Law \& Business 2011).

${ }^{24}$ Id.

${ }^{25}$ WishaRt M., CONTRACT LAW (2012), supra note 20.
} 
Any party granting such interest may only create a security interest in whichever rights contained in the collateral, irrespective of whether they comprise of absolute ownership or lesser rights including leasehold interest. ${ }^{26}$ The UCC often demands for a written or electronic security understanding describing the security authenticated by the electronic related form of signature. It also outlines how the agreement is to portray the collateral. Such description entails a set of governing rules, thus, terms like "all assets" remain void in a security agreement. Alternatively, the UCC develops a set of guidelines for how such security is to be described. ${ }^{27}$ Oral security agreements become rare but possible for commercial transactions.

The ascription of a security interest remains to be valid between the borrower and the secured party which entitles the latter to implement resolves if due. Nonetheless, the secured party ought to enhance the interest against future parties (third), especially future creditors of the same borrower and any trustee in bankruptcy in case the borrower files bankruptcy. Two main methods stand out under UCC in the perfection of a security interest in goods: filing of sufficient financing statement, and possessing of the goods by the secured party. ${ }^{28}$

The financial statement describes a filing aimed at placing other creditors on notice of the secured party's collateral interest as recognized by the financing statement. It must comprise of information on the grantor and the secured party such as the address and a brief highlight of the collateral. Essentially, the grantor's name becomes of utmost importance: it must correspond appropriately to the grantor's legal name. ${ }^{29}$ The method is valid for description of the collateral as "all assets" as long as the security agreement allows it. This does not occur sufficiently in a security agreement.

Most collateral involve an adequate single financing statement in the location of the debtor. The type of debtor determines the proper location. For instance, if the debtor includes a local corporation or a limited liability company, the location usually falls in the state under whose guidelines they were governed. A common individual acquires his location at the place of principal residence. ${ }^{30}$ For foreign chartered organizations, trusts, firms under the federal law and so on obtain special rules of governance. Such statements generally apply in use for five years after filing unless there exists a continuation statement filed six months before the lapse period. A

\footnotetext{
${ }^{26}$ KLASS G., CONTRACT LAW IN THE USA (2010), supra note 12.

${ }^{27}$ EUROPEAN COMMISSION, CONTACT LAW (2013), supra note 22.

${ }^{28}$ Young M., UnDERSTANDING CONTRACT LAW (2009), supra note 8.

${ }^{29}$ Wishart M., Contract LaW (2012), supra note 20.

${ }^{30}$ KLASS G., CONTRACt LAW IN THE USA (2010), supra note 12.
} 
new statement or amendment will be needed in case there are changes in the name, firm's structure or location of the grantor before expiry of the instrument.

The perfection of a security interest by a secured party through possession prompts him to involve a third party in such possession on behalf of the secured party. However, it remains clear that, the third party lacks the right to a debtor. In cases where the collateral entails a set of goods evidenced through a bill of lading, receipt from a warehouse or any corresponding document, a secured party may perfect such interest by taking particular actions regarding the document, instead of filing a UCC financing statement. For negotiable documents, the secured party can as well take possession of it. ${ }^{31}$ As an alternative he can also notify the document issurer of the security interest or issue such document in the name of the secured party.

Where a secured party is in possession of a perfected security interest in collateral with the collateral resulting to proceeds, the secured party automatically obtains a perfected security in such proceeds for twenty days after receipt to the borrower. On expiry of the twenty-day period, a security interest in identifiable proceeds from cash remains in perfection. Other types of goods receive special treatment in terms of the governing laws ascribed to them outside the scope of the UCC. ${ }^{32}$ Common examples include ships and aircraft: perfection of security interest in aircrafts and related assets demands for registration at the international registry located in Oklahoma; for ships, filing a mortgage with the Secretary of Transportation becomes an essential requirement.

Guidelines provided by the UCC distinguish between the various financial instruments. The most common forms include investment property, deposit accounts, instruments and chattel papers. Investment property includes debt and equity securities, security accounts, commodities contracts and commodities accounts. Deposit accounts entail demand accounts, time accounts, savings accounts and passbook accounts. Instruments encompass such written evidence showing proof of payment, but not including leases or certified security, for example, a promissory note. ${ }^{33}$ Lastly, chattel papers describe proof of monetary duty with a security interest in, or lease of, particular inventory. They can either be written or electronic, such as sale of a certain motor vehicle.

\footnotetext{
${ }^{31}$ Commission on European Contract LaW, Principles of European Contract LaW (1999), supra note 5.

${ }^{32}$ Wishart M., CONTRACT LAW (2012), supra note 20.

${ }^{33}$ Cisg.LAW., InTROdUCtion to PRINCIPLES OF EUROPEAN CONTRACT LAW (2010), supra note 4.
} 
Perfection is carried out by the secured party through a filing of a UCC financing statement for either instrument. Investment property, chattel papers and instruments hold the secured party as a priority over another party having perfected its interest singly through filing, irrespective of the period of filing. Security interest in instruments, incorporeal chattel paper and securities obtain perfection by possession. ${ }^{34}$ Such perfection requires no endorsement, but capable of resulting benefits. Thus, an endorsement in blank becomes common for both instruments and certified securities.

For uncertified securities, electronic chattel paper, deposit accounts, and commodity accounts perfection by possession will not suffice, but rather through "control”. Deposit accounts, for instance, may involve a control agreement between the debtor, the secured party and the bank representing the intermediary in securities maintaining the account. ${ }^{35}$ In such an agreement, the acting intermediary comes into agreement with the secured party to comply with the leveled instructions without further consent of the debtor. Other methods for achieving control are provided for by UCC. For instance, the secured party becomes the registered owner of an uncertified security, or the account holder of a deposit or securities account. Some situations allow the secured party too be in automatic control as in cases where the secured party depicts as the intermediary maintaining the account.

Other assets under personal property are classified into claims and receivables and generally comprise of accounts, commercial tort claims, letter of credit rights, and general intangibles. The policies governing such property correspond in a similar way to those for goods. However, commercial tort claims demand for particular identification of resulting claims as relates to the security interest. Security interest in these forms of property usually evokes concerns of whether the debtor ought to assign its interest to the secured party. ${ }^{36}$ The UCC is mandated to prevail over certain limitations on assignment either in full or part. It also becomes a necessity to comply with special requirements as provided in the statutes in cases where the obligor on any claim involves a government entity.

Perfection of a security interest for these properties entails the common UCC financing statement. In a letter of credit, such approach does not suffice. It requires the issurer to agree to an assignment of the proceeds of the claim (letter of credit) to the secured party. In situations where the claim agrees to payment or performance of any account, document, instrument,

\footnotetext{
${ }^{34}$ Wishart M., CONTRACT LAW (2012), supra note 20.

${ }^{35}$ KLASS G., CONTRACT LAW IN THE USA (2010), supra note 12.

${ }^{36}$ Young M., Understanding ConTRACT LAW (2009), supra note 8.
} 
intangible, and so on, the UCC terms such letter of credit as a "supporting obligation". Here, the secured party automatically acquires a perfected security interest on perfection, resulting as a supporting obligation. This, however, limits the secured party from drawing on the letter of credit, unless the debtor transfers it to the secured party.

\section{SECURITY RIGHTS IN IMMOVABLES AND CONTRACT LAW}

Immovables or real property entail items of property that cannot be transferred from one place to another due to permanent fixation such as land or buildings. It thus includes land and typically anything erected on, fixed to or growing on it. Such property can only experience movement when altered or destroyed. It is commonly referred to as real estate in the USA, and simply as property in Britain. ${ }^{37}$ The term includes buildings and property rights such as inheritance rights, land located on or below the Earth, or having a fixed address. No changes are made to immovable property without clear consent from the owner.

\section{A. United States}

In the USA, real property security tools differ according to various states. Mortgages remain to be the most common security instruments encumbering any interest in real property having legal transfer. This includes transfer of full ownership, interest under lease due to the tenant or interest due to a beneficiary of an easement. ${ }^{38}$ If the party granting the mortgage (mortgagor) defaults in payment or performance of duty, the holder of the mortgage or the lender (mortgagee) may facilitate an auction sale of such property, with subsequent proceeds used towards the secured responsibility.

An alternative form of instrument also includes deeds of trust: the borrower under this approach transfers title to any immovable to a third party trustee. The trustee can either transfer back the instrument after payment of loan or hold a trustee's sale in case of loan defaultment. Thus, the lender remains in the same position as if held by a mortgage. Application of mortgages result in lack of ownership of the security until a foreclosure or trustee's sale is made. The lender cannot, therefore, receive revenue from the rental property before occurrence of a sale. ${ }^{39}$ As a matter

\footnotetext{
${ }^{37}$ Alpa G., Bar C., Drobnig U. \& European Commission, (2004), supra note 1.

${ }^{38}$ MoOtz F. J., Principles OF AMERICAN Contract LAW (2011), supra note 23.

${ }^{39}$ KLASS G., CONTRACT LAW IN THE USA (2010), supra note 12.
} 
of response, lenders demand that, borrowers separately assign such income to the lender, from the time of closure, in order for the lender to collect the incomes on any arrears. This arises without the need of waiting for a foreclosure or a corresponding sale. The process is done in a separate document different from the mortgage or deed of trust.

All states demand that, the borrower takes ownership of any real property being mortgaged to the lender. This implies that, in case the borrower possesses a lease of such property, they have a leasehold interest, which may be mortgaged basing on the set terms of such lease, but cannot mortgage interest due to the landlord. It is required that, the borrower grants either of the security instruments through signing and recognizing a written document. ${ }^{40}$ The necessary technical needs vary across different states including description of the real property, language in use, and formalities arising from signatures.

For perfection of liens burdening on real property, the lender is required to make note of the security instrument used in the land covering its location. Recording demands compliance with the leveled technicalities, payment of taxes and legal fees, and conveyance of reinforcing documents. This does not present automatic or simple situations. ${ }^{41}$ It results in issuance of a title insurance policy, with a title insurance company assuring the lender of validity in the held lien that, encumbers the real property as described in the policy. The average costs for such coverage stands at $0.2 \%$ of the full amount of the lien under insurance. ${ }^{42}$

\section{B. Europe}

Real property shows development in Europe based on feudal and Roman law. The general contemporary sources become spread over continental codifications and the British common law with particular areas as apartment ownership being managed in special statutes. The law on immovables is highly influenced by liberalism relying heavily on individual ownership of land. Land ownership legally termed as dominium, represents the all-inclusive property right. ${ }^{43}$ Continental systems require that, ownership cannot be divided in different rights unless there exists "pioneer rights" including possession. Nonetheless, the common law provides for ownership on a limited time basis for estates.

\footnotetext{
${ }^{40}$ Mootz F. J., Principles of American Contract LaW (2011), supra note 23.

${ }^{41}$ KLASS G., CONTRACT LAW IN THE USA (2010), supra note 12.

${ }^{42}$ Wishart M., Contract LAW (2012), supra note 20.

${ }^{43}$ Simon J., European Contract LaW: Draft Code Published (2011), supra note 2.
} 
Security rights encompass the use of land as guarantee in rem for settlement of a debt. They require creation buy deed or notarial act, and registration in a land register. In the creation of a mortgage, the property becomes a possession of the owner. ${ }^{44}$ Conversely, with a default in payment, the land is sold at an auction or through another means of forced sale, which demands for authorization by a court action. The traditional English viewpoint of a mortgage saw the lender becoming the owner of such land, or being granted a long lease.

The most essential forms of security rights in rem consist of: mortgages developed from a credit contract by parties securing debt; liens enforced by statutes resulting from certain factual situations especially when the seller of land stays put due to default by the debtor, as in France and England; and rent charges which secure a periodic payment method on the land, usually for maintenance of the family, as in Germany. Some countries present other forms of securities in rem: Belgium laws create forms of securities known as mortgage promises which distinguish from full mortgages, aiding in avoiding high registration duties.

The major difference between mortgages under varied systems in Europe stands out in the nature of accessoriness. This describes the linkage of a mortgage to an existing debt secured as a result of the mortgage being minimized as the debt is gradually settled expiring completely once the debt lacks existence. ${ }^{45}$ The accessory concept mostly prevails in the English and French legal systems, with the non-accessory form dominant in Germany. It also exists in Finland, Sweden and some Eastern European states, with a corresponding approach being acknowledged under the polish legal rules. For the accessory form, a maximum of security is created for the debtor, while the non-accessory option facilitates the recurring use of a mortgage and its transferability among the involved parties, further enhancing the refinancing by banks.

\section{INTERACTION OF PROPERTY AND CONTRACT LAW ON SECURITY RIGHTS}

The key issue demanding resolve entails the conceptual and terminological variations between the fields of property law and contract. ${ }^{46}$ Thus, concerns of a unification of contract law with property law seek to harmonize the scope developed from both fields. The individual disturbing concept under contract law rests with the common view of contractual

\footnotetext{
${ }^{44}$ Young M., UnDERSTANDING CONTRACT LAW (2009), supra note 8.

${ }^{45}$ Alpa G., Bar C., Drobnig U. \& European Commission, (2004), supra note 1.

${ }^{46}$ Simon, J., European Contract LaW: Draft Code Published (2011), supra note 2.
} 
proprietary effects which influences the transfer of a proprietary right, either ownership of or security right in movables or immovables.

One key issue relates to the due influence of the contractual agreement. This entails the validity of the involved agreement which has to meet certain provisions, such as acceptance and consideration showing consent by the parties. Property rights are enhanced through legal and valid contracts pertaining to transfer of ownership to the subsequent holder. The passing of property rights from one party to another, either a second or third party, depends highly on the performance of the contractual agreement. Thus, contract formation involving property such as movables will require that, the contract formed conforms to all essential demands meant for a valid contract.

Another concern entails the element of free will binding the contractual parties, and corresponding to freedom of contract. Harmonization of property rights and the constitutive contracts thus requires a middle ground that allows for more flexibility, especially for civil law which considers the doctrine of numerus clausus as an essential part of property law. For instance, the system of civil law may employ lesser restrictions on property rights and common law systems formulate certain rights against the world through a standardization of those rights. The existences of mandatory rules of standardization are leveled to a certain point optimum for both circumstances.

\section{CONCLUSION}

Possible remedies remain relevant in order to mitigate on the interference of contract law with property law, with encouraged exclusion from the latter field of study. Legal systems employing the divided approach minimize on any undesirable effects of contract law through establishing separate, independent means for the institution or transfer of proprietary rights. Conflict laws become essential as sources of remedy as they overcome the differences between various legal systems without altering them in substance. A common remedy is use of grace periods for transactions involving different countries, since during this time, the security rights maintain their validity. In a nutshell, harmonization serves to provide a common global understanding as relates to contractual property law, suggesting similarities in security laws as the best solution. 